\title{
Brand Image Antecedents of Loyalty and Price Premium
}

\section{in Business Markets}

\author{
Niklas Bondesson \\ Lund University, Sweden \\ E-mail: niklas.bondesson@fek.lu.se
}

Received: January 23, 2012

Accepted: February 16, $2012 \quad$ Published: March 1, 2012

doi:10.5430/bmr.v1n1p32

URL: http://dx.doi.org/10.5430/bmr.v1n1p32

\begin{abstract}
The purpose of the present paper is to examine how brand image builds brand loyalty and price premium in business markets, focusing on the question of whether the same brand image elements incite customers' loyalty as well as causing them to pay more. A statistical analysis, based on a survey of professional packaging buyers in eight countries, reveals that brand loyalty and price premium are two distinct customer responses determined by different brand image elements. Associations to a brand's company reputation, service relationship ability, and product solution mainly build brand loyalty, whereas price premium is built solely by associations to the brand's community. The findings add to the existing B2B brand equity work by contributing a more nuanced understanding of the brand image-brand strength relationship and establishing price premium as a distinct and important brand strength indicator in business markets. It also provides a refined and highly detailed brand image model.
\end{abstract}

Keywords: Buyer-seller relationships, Brand equity, Business-to-business marketing, Industrial marketing, Brand image, Customer loyalty

Type: Research paper

\section{Introduction}

B2B brand equity is a field of research that is growing rapidly, as it becomes increasingly evident that branding is relevant to business markets and not only to consumer markets (Kotler \& Pfoertsch, 2006). The concept of brand equity has an explicit focus on extracting the tangible economic value from brands (Aaker, 1991; Keller, 1998) and is today a broad field that can be subdivided into a brand equity chain (Persson, 2010) with three components: brand image, brand strength, and brand value (see fig. 1). Models with a very similar logic have also been presented by Srivastava and Shocker (1991), Feldwick (1996), Wood (2000) and Kotler and Keller (2009), and the present chain can roughly be said to summarize the underlying common denominators in these.

\section{$===$ INSERT FIGURE 1 HERE $===$}

The visualized causal principle states that how target customers perceive a brand's specific attributes (brand image) will influence how they evaluate and respond to the brand globally (constituting the strength of a brand), which will influence the long-term economic value that the brand generates for the brand-owning firm (brand value). From a theoretical and managerial branding perspective, brand image and brand strength are perhaps the most interesting components: brand image, described as the information linked to a brand in the customer memory (Keller, 1993), because it deals with those customer-based associations that companies can attempt to influence with various efforts; and brand strength, because it deals with those customer responses that ultimately decide whether the brand will become valuable for the brand-owning firm. The extant general theory on brand equity mainly focuses on two types of brand strength: brand loyalty, empirically captured by such measures as recommendation, preference, and purchase intention (c.f. Cretu \& Brodie, 2007; Taylor, Geluch, \& Goodwin, 2004; Yoo \& Donthu, 2001), and customers' willingness to pay a price premium for a certain brand (c.f. Aaker, 1996; Netemeyer et al., 2004; Kalra \& Goodstein, 1998).

When it comes to B2B brand equity research specifically, important conceptual contributions have been made by Sharp (1995), Kim, Reid, Plank, and Dahlstrom (1998), Lynch and de Chernatony (2004), and Beverland, Napoli, and Lindgreen (2007), and a number of empirical studies have proven the existence of brand strength per se (Gordon, Calantone, \& Di Benetto, 1993; Firth, 1993; Hutton, 1997: Bendixen, Bukasa, \& Abratt, 2004; Walley, Custance, Taylor, Lindgreen, \& Hingley, 2007). In addition, a few empirical studies have been conducted to explore and validate different 
brand image elements (Mudambi, Doyle, \& Wong, 1997; Wiedmann, 2004; Kuhn, Alpert, \& Pope, 2008; van Riel, de Mortanges, \& Streukens, 2005; Cretu \& Brodie, 2007; Taylor et al., 2004; Han \& Sung, 2008; Beverland et al., 2007). Similar brand image models have, for example, been provided by Mudambi et al. (1997) and Persson (2010), the latter of which includes brand familiarity together with associations to a corporate B2B brand's product solution, services, distribution, relationship, and the company behind the offering.

The extant valuable contributions should definitely be built upon, but there is one question to which we do not yet have a detailed answer: do the same brand image elements that make business customers loyal also make them willing to pay a price premium? Researchers have only recently begun to link brand image and brand strength outcomes causally, but when doing so the focus has mainly been on brand loyalty determinants: why buyers "choose" (Mudambi et al., 1997), "select" (Kuhn et al., 2008), remain "loyal" to (van Riel et al., 2005; Wiedmann, 2004; Taylor et al., 2004), or "repeatedly purchase" (Han \& Sung, 2008) a brand. Such outcomes evidently reflect an interest in the volumes that B2B brands can sell. Researchers have to date been unable to provide rich enough data to describe and understand adequately whether the same brand image elements also drive price premiums in business markets.

There are indeed a few studies that include price premium. However, these are qualitative (Persson, 2010), make no systematic examination of the brand image determinants of price premium (Hutton, 1997), or, most commonly, lump price premium together with loyalty constructs into composite measures. One example is the study by Taylor et al. (2004), who combine price premium with four loyalty constructs, which can best be described as reflecting purchase intention, preference, commitment, and attachment, into a "loyalty" measure. This multi-item measurement approach is indeed common throughout the entire marketing field (c.f. Chaudhuri \& Holbrook, 2001), but becomes problematic when the combined items are not purely reflective - meaning that the different items that are combined are not one-dimensional, but actually reflect very different constructs (Diamantopoulos \& Winklhofer, 2001; Gerbing \& Anderson, 1988; Söderlund, 2006). As there is actually plenty of extant work on consumer markets to suggest that price premium and brand loyalty are distinct constructs (Ailawadi, Lehmann, \& Neslin, 2003; Netemeyer et al., 2004; Sethuraman, 2000), it seems unwise to combine them habitually in B2B research. If they are also distinct in business markets, any multi-item measure that combines them will conceal important nuances in terms of which brand image elements they are built upon.

The underlying assumption in the present paper is hence that a much richer understanding of how brand image drives brand strength, and consequently builds brand value, can be achieved by treating brand loyalty and price premium as two distinct customer responses to a favourable brand image. This focus is not only theoretically interesting, but also highly relevant from a managerial perspective, as the challenge for many firms revolves around striking a balance between the desire to obtain volume, market shares, and economies of scale and the desire for higher margins (cf. Dodd \& Favaro, 2006). One could argue that the current loyalty focus is mainly relevant to firms with a volume focus, and not to firms striving for a premium position.

The purpose of this paper is therefore to examine how brand image builds brand loyalty and price premium in business markets. This question is approached by first validating and refining a previously published conceptual brand image model (Persson, 2010), and then examining its causal relationship with brand loyalty and price premium. The focus will be on B2B brands at the corporate level, as today it is commonly assumed that B2B branding is the most relevant at the corporate level (Kuhn et al., 2008; Mudambi, 2002).

\section{Theoretical framework}

\subsection{Brand image in business markets}

Brand image definitions (eg. Keller, 1993; Feldwick, 1996) are rooted in theories on psychology and, most importantly, in the "associative network memory model" (see also Collins \& Loftus, 1975). Brand image refers to "the associations and beliefs the consumer has about the brand" (Feldwick, 1996), and basically any specific information existing in the minds of customers with respect to a brand is relevant as an image element. When it comes to specific B2B brand image elements, there are several conceptual and operational models to be found in the extant work (Mudambi et al., 1997; van Riel et al., 2005; Han \& Sung, 2008; Beverland et al., 2007). In this conceptual framework, and the subsequent empirical study, the explorative model presented by Persson (2010) will be used as a tentative starting point. It includes brand familiarity together with associations to a corporate B2B brand's product solution, services, distribution, relationship, and the company behind the offering.

Brand familiarity plays at least two roles in business markets: a buyer must be aware of a company in order to consider purchasing from it, but what is perhaps more important is that buyers perceive less risk in and tend to prefer well-known suppliers and producers (e.g. Dowling \& Staelin, 1994; McQuiston \& Dickson, 1991; Hutton, 1997). Apart from 
familiarity per se, it is of course important that a brand is known for something positive. Put simply, the product solution (quality, innovativeness, customization, etc.) and service elements (augmented service offerings, expertise, and advice) deal with a brand's core offering, and distribution with its perceived ability to distribute and deliver that offering to the right place at the right time. Relationship associations relate to perceptions about how the company - and the people behind the brand - interacts as a business partner on a daily basis, in terms of, for example, trustworthiness, cooperation, and adaptation. Finally, company associations have very little to do with the actual offering of a brand, but cover the general reputation of the company behind the brand in the marketplace, relating to such things as market leadership, personality, and management.

One advantage of the qualitatively based Persson (2010) model is that it was developed with a specific focus on understanding price premium antecedents. In addition, it is fairly broad and encapsulates most sub-elements from other models (c.f. Mudambi et al., 1997; van Riel et al., 2005), while at the same time being highly detailed and operational.

\subsection{Brand loyalty}

As loyalty has become an increasingly popular concept, it has also become increasingly rich, and can be measured in many different ways (Jacoby \& Chestnut, 1978; Dick \& Basu, 1994; Söderlund, 2006). One fundamental distinction can, for example, be made between attitudinal loyalty and behavioural loyalty (Day, 1969; Baldinger \& Rubinson, 1996). In the present paper, brand loyalty will be conceptualized as an attitudinal construct, in line with previous work on B2B brand equity (van Riel et al., 2005; Taylor et al., 2004; Cretu \& Brodie, 2007; Han \& Sung, 2008), making it fairly straightforward to compare brand image determinants of loyalty and price premium.

In the present study, brand loyalty is measured with two items that have commonly been combined in the existing B2B brand equity studies (Han \& Sung, 2008; van Riel et al., 2005; Cretu \& Brodie, 2007), as well as in studies within the broader marketing field (Zeithaml, Berry, \& Parasuraman, 1996; Auh \& Shih, 2005): purchase intention and recommendation. Both are conative, reflecting a "willingness to act" (Back \& Parks, 2003, p. 423), but while purchase intention focuses on the act of purchasing as such, recommendation focuses on the act of recommending a supplier to others, which is something that has been shown to drive future sales (Reichheld, 2003: Keiningham, Cooil, Andreassen, \& Aksoy, 2007).

\subsection{Price premium}

Within the consumer-oriented brand equity literature, several writers have treated price premium as a key brand strength (Netemeyer et al., 2004; Kalra \& Goodstein, 1998; Sethuraman, 2000; Ailawadi et al., 2003). A brand has a price premium when the sum customers are willing to pay for the products or services from a brand is higher than the sum they are willing to pay for similar offerings from other brands (Aaker, 1996). Measuring the price premium, as an attitudinal construct, is often undertaken with statements such as "Our company is willing to pay a higher price for products from this company than for similar products from other companies" (adapted from Netemeyer et al., 2004). A form of inverted price premium, price sensitivity, can also be used: "The prices of products from this company would have to go up quite a bit before we would consider another company" (cf. Han \& Sun, 2008; Netemeyer et al., 2004). Both are used in the present study.

\section{The study: professional packaging buyers}

The present study is based on 678 observations, drawn from a web survey completed by professional buyers of corrugated transport and consumer packaging in 8 countries across Europe. The survey measured customer-perceived brand image and brand loyalty regarding different packaging supplier brands. The access to respondents was gained thanks to a learning partnership programme between the university and a European-based supplier of packaging solutions that employs 24000 people and has sales of approximately 3.6 billion EUR a year (2008), across some 50 countries in Europe and Asia. The packaging industry has a seemingly strong focus on price. Several competing firms offer similar products and customers have a relatively strong bargaining power. The industry has gone through a consolidation, which has led to downward pressure on prices and margins

With only one single market in focus, it is difficult to generalize the findings directly to all business markets. On the other hand, an advantage of a single market focus is that it enables a highly detailed and aspect-rich understanding that is more difficult to attain if several different markets or industries are covered.

\subsection{Brand image and brand loyalty measurement scale}

In total, 47 items were used to measure empirically the 6 main elements of the Persson (2010) brand image model, their detailed sub-associations, brand loyalty, and price premium (Appendix A). Each respondent was asked to rate 3 different brands, along a 1-7 Likert scale: the cooperating partner brand, a global market leader brand, and a strong local brand 
(the local brands were different in different countries). All the items were framed at the organizational level, with a so-called key informant approach (see also Huntley, 2006; Ulaga \& Eggert, 2006) in which the respondents are asked to state their company's attitude rather than their own personal view. The specific questionnaire items were based primarily on existing B2B brand equity scales, but tailored to a packaging context when deemed necessary. The questionnaire was examined by experts, both business people from the partner company and academics, and pre-tested with four target customers, before being sent out.

\subsection{Sampling procedure and survey send-out}

The target population was defined as "target customers" to the partner company, including current customers as well as prospective customers that the case brand wants to have as customers, and multistage sampling was conducted (Biemer \& Lyberg, 2003). First, the market was divided into five naturally occurring geographical regions, of which two were sampled. Then, 8 countries from these two regions were sampled (Austria, the Czech Republic, Germany, Hungary, Poland, Slovakia, Sweden, and Romania), resulting in 29 of the partner company's production plants being included in the study. Together, the 29 selected plants have almost 15000 customer companies, and in addition a great number of prospect customers, but it was decided to focus on the top 30 current customer companies (in terms of purchase volumes) and top 10 prospect customer companies. Although 30 is a moderate figure, these customers together represents almost all revenues, while still having in a fair level of variation in size. In the next step, individuals were sampled, using a key informant approach, which is very common B2B marketing and branding research (c.f. Ulaga and Eggert 2006). The informant is not assumed to convey a perfectly representative picture of her or his organisation's view, but at least a valid enough view to base research on. Since not all the plants were able to provide full lists of individuals (some could only identify their top 20 customers, some had no prospect customers listed, etc.), the final sample consisted of 759 individuals from current customer companies and 160 individuals representing prospective customers. The fact that the number of current customers is larger than the number of prospective customers could be seen as a problem, but it does actually provide a good representation of the marketing reality that companies of this kind face. Invitations to the web survey were then sent by e-mail, and a number of measures were taken to boost the response rate, including Explicit mentioning of a university sponsorship, a non-monetary incentive and an anonymity insurance.

\subsection{Sample characteristics}

The survey was completed by 226 respondents (175 current customers and 37 prospective customers), representing a total response rate of $25 \%$, which can be seen as acceptable compared with similar studies (van Riel et al., 2005; Lam, Venkatesh, Erramilli, \& Murthy, 2004; Hutton, 1997). As each respondent was asked to rate 3 brands, the number of observations can be said to be 678 ( 226 respondents $\times 3$ brands).

The size of the responding companies ranged from small and medium-sized manufacturers to large multinationals. Most respondents stated that they work for companies in industrial industries (19\%), followed by the processed food industry $(18 \%)$, packaging $(8 \%)$, electronics $(7 \%)$, services $(1 \%)$, and other industries $(34 \%)$. More than half $(52 \%)$ of the responding key informants labelled themselves as members of a buying team, followed by $18 \%$ functioning as managers or senior managers. To validate the relevance of the key informant approach further, a question was asked about their influence on the choice of packaging supplier, for which the score 5.54 can be seen as acceptable (benchmarked to 5.78 in Ulaga \& Eggert's (2006) study).

\section{Findings and analysis}

As the measurement of brand image was based on a qualitative study (Persson, 2010), the first step in the analysis was to validate the dimensionality of this tentative model with a factor analysis.

\subsection{Validating and modelling B2B brand image}

Exploratory factor analysis with varimax rotation was conducted in several steps. Items were deleted until a meaningful and reliable model was found. The final solution includes 5 brand image factors based on 36 questionnaire items (summarized in Table 1; see full details in appendix B).

$$
===\text { INSERT TABLE } 1 \text { ABOUT HERE }===
$$

The factor analysis partly validates and partly refines the Persson (2010) model (originally including six dimensions: brand familiarity together with associations a corporate B2B brand's product solution, services, distribution, relationship, and the company behind the offering). One could have expected this statistical model to match the original one perfectly, but the obtained fit must be seen as acceptable considering that the original model was conceptual and based on exploratory qualitative research. 
The brand familiarity dimension is kept fully intact, and the product solution is also fully validated. The latter is dominated by associations relating to the material core of a firm's physical offering, or the "thing" it produces, which is a key dimension of most B2B brand image models (cf. Mudambi et al., 1997). In detailed terms, such associations as product aesthetics, innovativeness, and quality are covered. It also covers how products can be customized and bundled together with other products or services to create total solutions (see also Vargo \& Lusch, 2004; Beverland et al., 2007; Ballantyne \& Aitken, 2007).

The company dimension in the Persson (2010) model is divided into two factors. In the first factor, two specific items ("Being a customer to this company allows access to attractive business networks" and "Buying or using products from this company feels like belonging to a community") dominate with high loadings. They reflect a very specific form of company association relating to a brand's community, and target customers' feelings about being, or desire to be, involved with a brand and its other customers. More specifically, the first item deals with the social and economic aspects of a community (Andersen, 2005), while the other one deals with the psychological or invisible aspects of brand communities, defined as "an unbound group of brand admirers, who perceive a sense of community with other brand admirers, in the absence of social interaction" (Carlson, 2008). The remaining company associations are here simply labelled company reputation. Sometimes the term corporate reputation is used, but company reputation seems to be a more common term in the brand equity and industrial branding literature (see Cretu \& Brodie, 2007; Netemeyer et al., 2004; Bendixen et al., 2004; Mudambi et al., 1997). In this model, such associations as reputation, management, market leadership, excellence, and two brand personality items (where competence, intelligence, and successfulness show a particularly high factor loading) are included.

The relationship service factor is, in relation to the Persson (2010) model, basically an integration of most relationship and distribution associations (where most of the former show high factor loadings), together with two service items (service support and after-sales services). More specifically, it covers such associations as trustworthiness, ease of doing business, flexibility and adaptiveness, responsiveness, cooperation, friendliness of employees, reliability, and speed of deliveries.

\subsection{Main analysis: Relative impact of different brand image elements on brand loyalty and price premium}

First, an exploratory factor analysis was conducted to validate that brand loyalty and price premium are two distinct types of brand strength, which the results clearly confirm (Table 2). The scale reliability was also computed, showing satisfactory scores for both constructs.

\section{$===$ INSERT TABLE 2 ABOUT HERE===}

Then, a regression analysis was conducted in which brand loyalty and price premium were utilized as dependent variables (Table 3).

\section{$===$ INSERT TABLE 3 ABOUT HERE===}

The results demonstrate a good model fit for both brand strength variables, as indicated by the significant F-values ( $1 \%$ significance level). The VIF values show a low degree of multicollinearity, which means that the five factors are not correlated with each other to any critical degree. The total explanatory, or predictive, power of the brand image model is $64 \%$ for brand loyalty and $22 \%$ for price premium. Thus, the model is highly powerful in terms of explaining why target customers are loyal, but less powerful in explaining why target customers pay more or less for a supplier brand.

The most interesting finding, in relation to the purpose of the paper, is the obvious asymmetry when it comes to brand image determinants. Brand loyalty is significantly and positively related to all the brand image factors, of which company reputation is the single strongest antecedent. Price premium, in contrast, is positively related to only one single brand image factor, brand community, a finding that further underlines that brand loyalty and price premium are two distinct forms of customer response to a favourable brand image.

\subsection{In-depth analysis: Correlation analysis on the individual association level}

As a final step in the analysis, the individual brand image items were correlated with brand loyalty and price premium (fig. 2). Especially from a managerial perspective, this detailed analysis can provide much more specific and actionable insights than an analysis on the factor level, which by definition reduces the richness of the material.

\section{$===$ INSERT FIGURE 2 ABOUT HERE $===$}

Much can be said about the results in figure 2, but what is most interesting is how they further underline the importance of treating brand loyalty and the price premium as two different sub-dimensions of a brand's strength. In particular, two brand image items, "network" and "belonging" (see the full questionnaire items in appendix A), are very distinct drivers of target customers' willingness to pay. These associations correlate strongly with price premium but weakly with brand 
loyalty. In contrast, the associations to "employees and "trust" are strongly correlated with brand loyalty, but not positively correlated with price premium.

\section{Discussion}

\subsection{Different brand image elements drive brand loyalty and price premium}

The most formal theoretical contribution of this paper is a more nuanced understanding of the brand image-brand strength relationship in business markets than the existing B2B brand equity work provides. First of all, the findings clearly demonstrate that brand loyalty and price premium are two very distinct forms of brand strength. This is something that has been stressed previously by research in consumer markets (Netemeyer et al., 2004; Sethuraman, 2000; Ailawadi et al., 2003), but not in business markets in which most work has lumped them together into composite measures (c.f. Taylor et al., 2004) or focused solely on brand loyalty measures that have an underlying focus on the volumes a brand can sell (Mudambi et al., 1997; Kuhn et al., 2008; van Riel et al., 2005; Taylor et al., 2004).

Second, brand loyalty and price premium also have very different brand image antecedents. What makes buyers loyal, in terms of their intention to purchase and recommend a supplier brand, is simply not at all the same associations as what makes them pay more or less. It is the reputation of the company behind an offering that drives loyalty, followed by associations the service relationship and product solution that a supplier brand can offer that make target customers loyal. In sharp contrast, association to the community surrounding causes target customers to pay more. Asymmetries of this kind have indeed been demonstrated in the existing B2B brand equity work (Taylor et al., 2004), but then with a focus on different forms of brand loyalty and not on price premium.

Continuing to distinguish between the brand image drivers of price premium and brand loyalty should therefore bring us even closer to a general theory of B2B brand equity and provide guidelines for firms striving for higher margins rather than only large volumes. The present study clearly indicates that any composite conceptualization, or measurement, combining brand loyalty and price premium can conceal important nuances.

\subsection{Price premium is a distinct and important type of brand strength}

By giving price premium more attention as a distinct customer response, the present study can be said to provide a more balanced view of the brand strength concept than that displayed by the extant work (c.f. van Riel et al., 2005; Taylor et al., 2004; Han \& Sung, 2008). Taking both the volume and the price dimensions into account is, however, not only something that can be argued for based on the empirical findings in this study; there are several other reasons why it seems plausible. First, it underlines brand equity theory's focus on economic outcomes because of its compatibility with shareholder value theory (cf. Doyle, 2001; Srivastava, Shervani, \& Fahey, 1998), which states that greater volumes and higher prices are the two main ways in which market-based assets enhance a firm's levels of inflowing cash. Some writers, such as Doyle (2000), even argue that a price premium is the most important way in which brands create shareholder value, because it requires no direct investments to charge a higher price. Second, brand-owning companies themselves associate successful B2B branding not only with loyalty but also with price premiums (Shipley \& Howard, 1993; Michell, King, \& Reast, 2001). Finally, as already mentioned, it reflects very well the tension between volumes and margins that managers face (c.f. Dodd \& Favaro, 2006).

\subsection{Brand communities play an important role in the creation of B2B brand equity}

Since the brand community element emerged as particularly important, being the only image element that allows a supplier brand to charge a higher price, it deserves some further elaboration. The two measurement items that mainly compose this element in this study relate to two aspects of a community: the social and economic benefits that a community or network can provide (Andersen, 2005) and the psychological ties or sense of belonging that can occur between its members (Carlson, 2008). The results are probably the first to indicate empirically that the assumed positive impact of brand communities on brand loyalty (Muniz \& Guinn, 2001) can be true for B2B brands. Previously, it has only been systematically validated in consumer markets (McAlexander, Schouten, \& Koenig, 2002; Algesheimer, Dholakia, \& Herrmann, 2005). Additionally, the results are probably also the first, in any market, to reveal a strong significant relationship between brand communities and the ability to charge a price premium.

Adding the brand community element to B2B brand equity theory contributes a conceptual acknowledgement of how the image and strength of a brand are not only a result of customers' mental relationship with a B2B brand, but also a result of the social or psychological ties between the brand's customers.

\subsection{A validated five-dimensional brand image model}

Finally, on a more general level, an additional theoretical contribution from this study is the refinement and validation of a highly detailed B2B brand image model. It suggests that buyers' associative brand memory network can be understood 
as a five-dimensional brand image model, including brand familiarity, product solution, service relationship, brand community, and company reputation - dimensions that encapsulate a great number of detailed brand associations (see appendix). The model was refined based on Persson's (2010) exploratory work, which is partly validated, but to a large extent also confirms the relevance of elements that also occur in other models (c.f. Mudambi et al., 1997; van Riel et al., 2005).

In terms of explaining brand loyalty, the present brand image model is highly powerful as it explains $64 \%$ of the variation, which can be compared with van Riel et al.'s (2005) 56\%. It is, however, weaker in terms of explaining price premium (only 22\%). Principally, one reason behind the weaker power could be that further brand image elements must be identified and added in order to understand why buyers in business markets pay more or less for different brands. Another reason, however, could be the question of whether the measures of attitudinal price premium, taken from brand equity studies in consumer markets (cf. Netemeyer et al., 2004), are as useful in business markets. Looking in detail at the price premium data, they are highly skewed and show considerably lower mean scores than the loyalty data. There is no doubt that organizational buyers also pay price premiums for the brands they prefer (cf. Bendixen et al., 2004; Hutton, 1997; Firth, 1993), but the question is how this can best be measured with psychological constructs. With better measures of price premium, it is perhaps possible to obtain a better picture of their determinants.

\section{Managerial implications}

The study has serious implications for managers, especially in how it, in great detail, shows that companies must build different brand image elements depending on whether they are striving for greater sales volumes or greater margins. The former companies should definitely focus on the reputation of their companies as a whole, rather than communicating only which products and services they have to offer (which is often the case). A potentially more profitable position can revolve around an image of general excellence, being perceived as the leader of the industry, or being perceived as reliable, competent, and customer caring. In this particular study, specific associations to product innovativeness and with the width of the product portfolio can be found among the least loyalty and price premium driving companies. Product quality does not even emerge as a key association. Hence, what a B2B brand stands for and how it acts as a business partner can be more important than what it actually produces. This does not mean to say that B2B brands can never build a strong differentiated brand with product promises. A product-based positioning should obviously be a viable strategy for firms that are actually offering superior product performance (see also Beverland et al., 2007).

For brands that are chasing higher margins or niche positions, building or stimulating a brand community is a strategy that should be considered. A community can take a physical, digital, or psychological form, and it can be managed by the company itself or by its customers. A wide range of tools are available for this purpose: everything from clothing (Caterpillar), golf tournaments, and seminars to websites, extensive training programmes, exclusive think tanks, and advertising (such as SAP's "Lufthansa runs SAP" and "North Face runs SAP") can potentially stimulate bonds between a brand's customers.

\section{Limitations}

A number of limitations pertain to this study. First, with only one single market in focus, it is difficult to directly generalise the findings to all business markets. The findings can nevertheless be generalized cautiously to corporate B2B brands providing similar offerings. In other words: brands offering a commoditised product that is augmented by services (such as training or technical expertise), and that is a part of the customer's production process as well as the final product, but not directly marketed or sold to end-consumers. Another issue is the key informant approach, and the fact that the sample mainly consists of buyers. Since one distinguishing feature of organisational purchase decisions, as they typically are described, is that several people are involved, it is important to examine also others function. And, perhaps are their loyalty and willingness to pay price premium determined by other brand image elements. Similarly, this study is limited to attitudinal loyalty, and it is possible that behavioural loyalty outcomes have other brand image determinants.

\section{Suggestions for future research}

Future research will have to generate even more empirical data before we can formally describe and fully understand how brand image builds brand strength and brand value in business markets. There might be general patterns, across different types of industries, products, and brands. One reason why the company behind the product, in this study, is more important than the product itself could be that it deals with a commodity product augmented by services. After all, when services are involved, personal brand touch points usually become critical, subsequently meaning that the company behind an offering becomes important (de Chernatony \& McDonald, 1998; Berry, 1995). It is, however, 
currently difficult to draw parallels with previous studies of a similar kind, since very few of them have been specific regarding what type of B2B offering they have studied, and whether services are added to the core offering or not.

\section{References}

Aaker, D. A. (1991). Managing brand equity. San Francisco: Free Press.

Aaker, D. A. (1996). Measuring brand equity across products and markets. California Management Review, 38(3), 102-20. Aaker, J. L. (1997). Dimensions of brand personality. Journal of Marketing Research, 34(3), 347-356. http://dx.doi.org/10.2307/3151897

Ailawadi K. L., Lehmann, D. R., \& Neslin, S. A. (2003). Revenue premium as an outcome measure of brand equity. Journal of Marketing, 67(4), 1-17. http://dx.doi.org/10.1509/jmkg.67.4.1.18688

Algesheimer, R., Dholakia, U. M., \& Herrmann, A. (2005). The social influence of brand community: Evidence from European car clubs. Journal of Marketing, 69(3), 19-34. http://dx.doi.org/10.1509/jmkg.69.3.19.66363

Andersen, P. H. (2005). Relationship marketing and brand involvement of professionals through web-enhanced brand communities: The case of Coloplast. Industrial Marketing Management, 34(3), 285-297. http://dx.doi.org/10.1016/j.indmarman.2004.07.007

Auh, S., \& Shih C.-F. (2005). The relative effects of relationship quality and exchange satisfaction on customer loyalty. Journal of Business to Business Marketing, 12(2), 73-100. http://dx.doi.org/10.1300/J033v12n02_03

Back, K.-J., \& Parks, S. C. (2003). A brand loyalty model involving cognitive, affective, and conative brand loyalty and customer satisfaction. Journal of Hospitality and Tourism Research, 27(4), 419-435. http://dx.doi.org/10.1177/10963480030274003

Baldinger, A., \& Rubinson, J. (1996). Brand loyalty: The link between attitude and behaviour. Journal of Advertising Research, 36(6), 22-34

Ballantyne, D., \& Aitken, R. (2007). Branding in B2B markets: Insights from the service-dominant logic of marketing. Journal of Business \& Industrial Marketing, 22(6), 363-371. http://dx.doi.org/10.1108/08858620710780127

Baxter, R., \& Matear, S. (2004). Measuring intangible value in business-to-business buyer-seller relationships: An intellectual capital perspective. Industrial Marketing Management, 33(6), 491-500. http://dx.doi.org/10.1016/j.indmarman.2004.01.008

Bendixen, M., Bukasa, K. A., \& Abratt, R. (2004). Brand equity in the business-to-business market. Industrial Marketing Management, 33, 371-380. http://dx.doi.org/10.1016/j.indmarman.2003.10.001

Beverland, M., Napoli, J., \& Lindgreen, A. (2007). Industrial global brand leadership. Industrial Marketing Management, 36, 1082-1093. http://dx.doi.org/10.1016/j.indmarman.2006.08.007

Berry, L. L. (1995). Relationship marketing of services: Growing interest, emerging perspectives. Journal of the Academy of Marketing Science, 23, 236-245. http://dx.doi.org/10.1177/009207039502300402

Biemer, P. P., \& Lyberg, L. E. (2003). Introduction to survey quality. New York: John Wiley. http://dx.doi.org/10.1002/0471458740

Carlson, B. (2008). Social versus psychological brand community: The role of psychological sense of brand community. Journal of Business Research, 61(4), 284-291. http://dx.doi.org/10.1016/j.jbusres.2007.06.022

Chaudhuri, A., \& Holbrook, M. B. (2001). The chain of effects from brand trust and brand affect to brand performance: The role of brand loyalty. Journal of Marketing, 65, 81-93. http://dx.doi.org/10.1509/jmkg.65.2.81.18255

Collins, A. M., \& Loftus, E. F. (1975). A spreading-activation theory of semantic processing. Psychological Review, 82(6), 407-428. http://dx.doi.org/10.1037/0033-295X.82.6.407

Cretu, A. E., \& Brodie, R. (2007). The influence of brand image and company reputation where manufacturers market to small firms: A customer value perspective. Industrial Marketing Management, 36, 230-240. http://dx.doi.org/10.1016/j.indmarman.2005.08.013

Day, G. S. (1969). “A two-dimensional concept of brand loyalty. Journal of Advertising Research, 9, 29-35.

De Chernatony, L. D., \& McDonald, M. (1998). Creating powerful brands. Oxford: Elsevier/Butterworth-Heinemann.

Diamantopoulos, A., \& Winklhofer, H. M. (2001). Index construction with formative indicators: An alternative to scale development. Journal of Marketing Research, 38(2), 269-277. http://dx.doi.org/10.1509/jmkr.38.2.269.18845 
Dick, A. S., \& Basu, K. (1994). Customer loyalty: Toward an integrated conceptual framework. Journal of Academy Marketing Science, 22(2), 99-114. http://dx.doi.org/10.1177/0092070394222001

Dodd, D., \& Favaro, K. (2006). Managing the right tension. Harvard Business Review, 84(12), 62-74.

Doney, P. M., \& Cannon, J. P. (1997). An examination of the nature of trust in buyer-seller relationships. Journal of Marketing, 61(2), 35-51. http://dx.doi.org/10.2307/1251829

Dowling, G. R., \& Staelin, R. (1994). A model of perceived risk and intended risk-handling activity. Journal of Consumer Research, 21(1), 119-13. http://dx.doi.org/10.1086/209386

Doyle, P. (2001). Shareholder-value-based brand strategies. Journal of Brand Management, 9(1), 20-30. http://dx.doi.org/10.1057/palgrave.bm.2540049

Feldwick, P. (1996). What is brand equity anyway, and how do you measure it? Journal of Market Research Society, 38, 85-104.

Gerbing, D. W., \& Anderson, J. C. (1988). An updated paradigm for scale development incorporating unidimensionality and its assessment. Journal of Marketing Research, 25, 187-92. http://dx.doi.org/10.2307/3172650

Gordon, G. I., Calantone, R. J., \& Di Benetto, C. A. (1993). Brand equity in the business-to-business sector: An exploratory study. Journal of Product and Brand Management, 2(3), 4-16. http://dx.doi.org/10.1108/10610429310046689

Firth, M. (1993). Price setting and the value of a strong brand name. International Journal of Research in Marketing, 10(4), 381-386. http://dx.doi.org/10.1016/0167-8116(93)90020-Y

Han, S.-L., \& Sung, H.-S. (2008). Industrial brand value and relationship performance in business markets - A general structural equation model. Industrial Marketing Management, 37, 807-818. http://dx.doi.org/10.1016/j.indmarman.2008.03.003

Huntley, J. K. (2006). Conceptualisation and measurement of relationship quality: Linking relationship quality to actual sales and recommendation intention. Industrial Marketing Management, 35, 703-714. http://dx.doi.org/10.1016/j.indmarman.2005.05.011

Hutton, J. G. (1997). A study of brand equity in an organizational-buying context. Journal of Product and Brand Management, 6(6), 428-39. http://dx.doi.org/10.1108/10610429710190478

Jacoby, J., \& Chestnut, R. (1978). Brand loyalty: Measurement and management. New York: John Wiley \& Sons.

Kalra, A., \& Goodstein, R. C. (1998). The impact of advertising positioning strategies on consumer price sensitivity. Journal of Marketing Research, 35(2), 210-25. http://dx.doi.org/10.2307/3151849

Keiningham, T. L., Cooil, B., Andreassen, T., \& Aksoy, L. (2007). A longitudinal examination of net promoter and firm revenue growth. Journal of Marketing, 71, 39-51. http://dx.doi.org/10.1509/jmkg.71.3.39

Keller, K. L. (1993). Conceptualizing, measuring, and managing customer-based brand equity. Journal of Marketing, 57(1), 1-23. http://dx.doi.org/10.2307/1252054

Keller, K. L. (1998). Strategic brand management, building, measuring, and managing brand equity. Upper Saddle River: Prentice-Hall.

Keller, K. L. (2001). Building customer-based brand equity. Marketing Management, 10(2), 14-19.

Kim, J., Reid, D. A., Plank, R. E., \& Dahlstrom, R. (1998). Examining the role of brand equity in business markets: A model, research propositions, and managerial implications. Journal of Business-to-Business Marketing, 5(3), 65-90. http://dx.doi.org/10.1300/J033v05n03_04

Kotler, P., \& Keller, K. L. (2009). Marketing management (13th edition). New Jersey: Prentice Hall.

Kotler, P., \& Pfoertsch, W. (2006). B2B brand management. Heidelberg/New York: Springer.

Kuhn, K.-A. L., Alpert, F., \& Pope, N. K. (2008). An application of Keller's brand equity model in a B2B context. Qualitative Market Research: An International Journal, 11(1), 40-58. http://dx.doi.org/10.1108/13522750810845540

Kumar, N., Scheer, L. K., \& Steenkamp, J.-B. E. M. (1995). The effects of perceived interdependence on dealer attitudes. Journal of Marketing Research, 32(3), 348-356. http://dx.doi.org/10.2307/3151986

Lam, S. Y., Venkatesh, S. M., Erramilli, M. K., \& Murthy, B. (2004). Customer value, satisfaction, loyalty, and switching costs: An illustration from a business-to-business service context. Journal of the Academy of Marketing Science, 32(3), 293-311. http://dx.doi.org/10.1177/0092070304263330 
Lau, G. T., \& Lee, S. H. (1999). Consumers' trust in a brand and the link to brand loyalty. Journal of Market-Focused Management, 4(4), 341-370. http://dx.doi.org/10.1023/A:1009886520142

Lynch, J., \& de Chernatony, L. (2004). The power of emotion: Brand communication in business-to-business markets. Journal of Brand Management, 11(5), 403-419. http://dx.doi.org/10.1057/palgrave.bm.2540185

McAlexander, J. H., Schouten, J. W., \& Koenig, H. F. (2002). Building brand community. Journal of Marketing, 66(1), 38-54. http://dx.doi.org/10.1509/jmkg.66.1.38.18451

McQuiston, D. H., \& Dickson, P. R. (1991). The effect of perceived personal consequences on participation and influence in organizational buying. Journal of Business Research, 23(2), 159-177. http://dx.doi.org/10.1016/0148-2963(91)90026-T

Menon, A., Homburg, C., \& Beutin, N. (2005). Understanding customer value in business-to-business relationships. Journal of Business-to-Business Marketing, 12(2), 1-38. http://dx.doi.org/10.1300/J033v12n02_01

Michell, P., King, J., \& Reast, J. (2001). Brand values related to industrial products. Industrial Marketing Management, 30(5), 415-425. http://dx.doi.org/10.1016/S0019-8501(99)00097-8

Mudambi, S. (2002). Branding importance in business-to-business markets: Three buyer clusters. Industrial Marketing Management, 31(6), 525-533. http://dx.doi.org/10.1016/S0019-8501(02)00184-0

Mudambi, S. M., Doyle, P., \& Wong, V. (1997). An exploration of branding in industrial markets. Industrial Marketing Management, 26(5), 433-446. http://dx.doi.org/10.1016/S0019-8501(96)00151-4

Muniz, M., \& O'Guinn, T. C. (2001). Brand community. Journal of Consumer Research, 27(4), 412-432. http://dx.doi.org/10.1086/319618

Netemeyer, R. G., Krishnan, B., Pullig, C., Wang, G., Yagci, M., Dean, D., Ricks, J. et al. (2004). Developing and validating measures of facets of customer-based brand equity. Journal of Business Research, 57(2), 209-224. http://dx.doi.org/10.1016/S0148-2963(01)00303-4

Persson, N. (2010). An exploratory investigation of the elements of B2B brand image and its relationship to price premium. Industrial Marketing Management, 39(8), 1269-1277. http://dx.doi.org/10.1016/j.indmarman.2010.02.024

Reichheld, F. F. (2003). The one number you need to grow. Harvard Business Review, December, 46-54.

Seth, N., Deshmukh, S. G., \& Vrat, P. (2006). SSQSC: A tool to measure supplier service quality in supply chain. Production Planning and Control, 17(5), 448-463. http://dx.doi.org/10.1080/09537280600741764

Sethuraman, R. (2000). What makes consumers pay more for national brands than for private labels: Image or quality? Marketing Science Institute Special Report. Cambridge, MA.

Sharp, B. (1995). Brand equity and market-based assets of professional service firms. Journal of Professional Services Marketing, 13(1), 3-13. http://dx.doi.org/10.1300/J090v13n01_02

Shipley, D., \& Howard, P. (1993). Brand-naming industrial products. Industrial Marketing Management, 22(1), 59-66. http://dx.doi.org/10.1016/0019-8501(93)90021-X

Srivastava, R. K., \& Shocker, A. D. (1991). Brand equity: A perspective on its meaning and measurement. Marketing Science Institute Special Report. Cambridge, MA.

Srivastava, R. K., Shervani, T. A., \& Fahey, L. (1998). Market-based assets and shareholder value: A framework for analysis. Journal of Marketing, 62(1), 2-18. http://dx.doi.org/10.2307/1251799

Söderlund, M. (2006). Measuring customer loyalty with multi-item scales: A case for caution. International Journal of Service Industry Management, 17(1), 76-98. http://dx.doi.org/10.1108/09564230610651598

Taylor, S. A., Geluch, K., \& Goodwin, S. (2004). The importance of brand equity to customer loyalty. The Journal of Product and Brand Management, 13(4/5), 217-227. http://dx.doi.org/10.1108/10610420410546934

Ulaga, W., \& Eggert, A. (2006). Relationship value and relationship quality broadening the nomological network of business-to business relationships. European Journal of Marketing, 40(3/4), 311-327. http://dx.doi.org/10.1108/03090560610648075

Van Riel, A. C. R., de Mortanges, C. P., \& Streukens, S. (2005). Marketing antecedents of industrial brand equity: An empirical investigation, in speciality chemicals. Industrial Marketing Management, 34, 841-847. http://dx.doi.org/10.1016/j.indmarman.2005.01.006

Vargo, S. L., \& Lusch, R. F. (2004). Evolving to a new dominant logic for marketing. Journal of Marketing, 68(1), 1-17. http://dx.doi.org/10.1509/jmkg.68.1.1.24036 
Walley, K., Custance, P., Taylor, S., Lindgreen, A., \& Hingley, M. (2007). The importance of brand in the industrial purchase decision: A case study of the UK tractor market. Journal of Business and Industrial Marketing, 22(6), 383-393. http://dx.doi.org/10.1108/08858620710780145

Wiedmann, K.-P. (2004). Measuring brand equity for organising brand management in the energy sector: A research proposal and first empirical hints. Journal of Brand Management, 12(2), 24-138. http://dx.doi.org/10.1057/palgrave.bm.2540209

Woo, K., \& Ennew, C. T. (2004). Business-to-business relationship quality: An IMP interaction-based conceptualization and measurement. European Journal of Marketing, 38(9/10), 1252-1271. http://dx.doi.org/10.1108/03090560410548960

Wood, L. (2000). Brands and brand equity: Definition and management. Management Decision, 38(9), 662-669. http://dx.doi.org/10.1108/00251740010379100

Yoo, B., \& Donthu, N. (2001). Developing and validating a multidimensional consumer-based brand equity scale. Journal of Business Research, 52(1), 1-14. http://dx.doi.org/10.1016/S0148-2963(99)00098-3

Zeithaml, V. A., Berry, L., \& Parasuraman, A. (1996). The behavioral consequences of service quality. Journal of Marketing, 60(2), 31-46. http://dx.doi.org/10.2307/1251929

\section{APPENDICES}

\section{Appendix A. Questionnaire items (measurement scale for brand image, brand loyalty, and price premium). BRAND IMAGE}

Brand familiarity (items based on Netemeyer et al., 2004; van Riel et al., 2005).

Recognition: When I think of packaging, this company comes first to mind

Knowledge: I know what this company stands for and has to offer

Product solution associations (van Riel et al., 2005; Doney \& Cannon, 1997; Menon, Homberg, \& Beutin, 2005; Cannon \& Pereault, 1999).

Style: Stylish and modern products

Innovation: Innovative products

Portfolio: Broad product portfolio covering any packaging need

Process: Products easy to process

End-user value: Products highly valued by end-users

Customization: Customizes to meet specific customer needs

Solution: Provides total solutions

Product quality: High-quality products

Basic need: This company satisfies the basic needs of packaging

Service relationship associations (Mudambi et al., 1997; Keller, 2001; Woo \& Ennew 2004; van Riel et al., 2005; Doney \& Cannon, 1997; Seth, Deshmukh, \& Vrat, 2006; Menon et al., 2005).

Delivery speed: Speedy deliveries

Commitment: Strongly committed to its customers

Trust: Trustworthy

Ease of business: Easy to do business with

Flexibility: Flexible and adaptive

Responsiveness: Responsive 
Delivery reliability: Reliable deliveries

Cooperation: Cooperative and partnership-oriented

Ordering: Easy ordering

Employees: Nice and friendly employees

Availability: Products always available

Support: Excellent service support

Service: Excellent after-sales services and problem shooting

Company reputation associations (van Riel et al., 2005; Cretu \& Brodie, 2007; Keller, 2001; Doney \& Canon, 1997; Baxter \& Matear, 2004; Lau \& Lee, 1999; Aaker, 1997).

Management: A well-managed company

Competence: Competent, intelligent, and successful

Reliability: A safe, reliable choice

Customer care: Has the customers' best interest in mind

Reputation: Has a good reputation

Excellence: Sets the standard for excellence

Leadership: Industry leader

Sophistication: Sophisticated, smooth, and charming

Brand community associations (Baxter \& Matear, 2004; Kumar, Scheer, \& Steenkamp, 1995; Algesheimer et al., 2005; Aaker, 1997).

Network: Being a customer of this company allows access to attractive business networks

Belonging: Buying or using products from this company feels like belonging to a community

Excitement: Exciting, spirited, and daring

Uniqueness: Unique compared with competitors

\section{BRAND STRENGTH}

Brand loyalty (Han \& Sung, 2008; van Riel et al., 2005; Cretu \& Brodie, 2007; Zeithaml et al., 1996; Auh \& Shih, 2005).

Short-term purchase intention: The next time our company buys packaging, we will likely buy from this company

Long-term purchase intention: Our company would like to do more business with this company in the future

Recommendation: How likely is it that you would recommend this company to a friend or colleague?

Price premium (Netemeyer et al., 2004; Han \& Sun, 2008).

Price premium: Our company is willing to pay a higher price for packaging from this company than for similar products from other companies

Price premium 2: Our company is willing to pay a lot more for packaging from this company

Price sensitivity: The prices of products from this company would have to go up quite a bit before we would consider another company 
Appendix B. Factor analysis of brand image

\begin{tabular}{|c|c|c|c|c|c|c|c|}
\hline & \multicolumn{5}{|c|}{ Rotated component matrix } & \multirow[b]{2}{*}{$\begin{array}{l}\text { Commu-n } \\
\text { alities }\end{array}$} & \multirow[b]{2}{*}{$\begin{array}{c}\text { Analysis } \\
\mathrm{N}\end{array}$} \\
\hline & $\begin{array}{c}\text { Service } \\
\text { relationship }\end{array}$ & $\begin{array}{c}\text { Product } \\
\text { solutions }\end{array}$ & $\begin{array}{c}\text { Company } \\
\text { reputation }\end{array}$ & $\begin{array}{c}\text { Brand } \\
\text { community }\end{array}$ & $\begin{array}{c}\text { Brand } \\
\text { familiarity }\end{array}$ & & \\
\hline Delivery speed & 0.77 & 0.21 & 0.07 & 0.15 & 0.26 & 0.73 & 411 \\
\hline Commitment & 0.75 & 0.34 & 0.31 & 0.17 & -0.04 & 0.80 & 426 \\
\hline Trust & 0.74 & 0.27 & 0.39 & 0.00 & 0.21 & 0.82 & 427 \\
\hline Ease of business & 0.74 & 0.31 & 0.29 & 0.07 & 0.17 & 0.76 & 424 \\
\hline Flexibility & 0.73 & 0.21 & 0.41 & 0.14 & 0.14 & 0.78 & 417 \\
\hline Responsiveness & 0.72 & 0.25 & 0.29 & 0.17 & 0.14 & 0.71 & 421 \\
\hline Delivery reliab. & 0.72 & 0.23 & 0.33 & 0.11 & 0.22 & 0.73 & 420 \\
\hline Cooperation & 0.69 & 0.37 & 0.35 & 0.17 & -0.02 & 0.77 & 427 \\
\hline Ordering & 0.68 & 0.30 & 0.26 & 0.06 & 0.26 & 0.70 & 412 \\
\hline Employees & 0.64 & 0.33 & 0.43 & -0.10 & 0.20 & 0.75 & 426 \\
\hline Availability & 0.64 & 0.22 & 0.17 & 0.28 & 0.15 & 0.58 & 408 \\
\hline Support & 0.61 & 0.45 & 0.34 & 0.09 & 0.25 & 0.77 & 437 \\
\hline Service & 0.59 & 0.45 & 0.35 & 0.19 & 0.08 & 0.71 & 417 \\
\hline Style & 0.21 & 0.82 & 0.28 & 0.16 & 0.13 & 0.84 & 422 \\
\hline Innovation & 0.23 & 0.74 & 0.35 & 0.13 & 0.19 & 0.77 & 450 \\
\hline Portfolio & 0.42 & 0.73 & 0.07 & 0.04 & 0.09 & 0.72 & 447 \\
\hline Process & 0.30 & 0.68 & 0.17 & 0.17 & 0.36 & 0.74 & 425 \\
\hline End-user value & 0.27 & 0.67 & 0.06 & 0.34 & 0.16 & 0.67 & 402 \\
\hline Customization & 0.51 & 0.63 & 0.26 & 0.04 & 0.07 & 0.74 & 438 \\
\hline Solution & 0.48 & 0.63 & 0.30 & 0.10 & 0.00 & 0.73 & 424 \\
\hline Product quality & 0.31 & 0.58 & 0.41 & 0.01 & 0.46 & 0.80 & 473 \\
\hline Basic need & 0.46 & 0.56 & 0.30 & -0.06 & 0.43 & 0.81 & 473 \\
\hline Management & 0.33 & 0.25 & 0.74 & 0.17 & 0.13 & 0.76 & 389 \\
\hline Competence & 0.37 & 0.21 & 0.70 & 0.24 & 0.05 & 0.73 & 377 \\
\hline Reliability & 0.51 & 0.15 & 0.68 & 0.13 & 0.23 & 0.81 & 433 \\
\hline Customer care & 0.40 & 0.16 & 0.66 & 0.28 & 0.02 & 0.70 & 407 \\
\hline Reputation & 0.32 & 0.22 & 0.65 & 0.06 & 0.36 & 0.70 & 458 \\
\hline Excellence & 0.33 & 0.26 & 0.61 & 0.45 & -0.03 & 0.75 & 341 \\
\hline Leadership & 0.24 & 0.29 & 0.58 & 0.24 & 0.17 & 0.56 & 402 \\
\hline Sophistication & 0.29 & 0.14 & 0.51 & 0.50 & 0.04 & 0.61 & 330 \\
\hline Network & 0.03 & 0.04 & 0.07 & 0.87 & 0.11 & 0.77 & 342 \\
\hline Belonging & 0.13 & 0.02 & 0.10 & 0.83 & 0.21 & 0.76 & 366 \\
\hline Excitement & 0.23 & 0.21 & 0.43 & 0.60 & -0.17 & 0.67 & 335 \\
\hline Uniqueness & 0.02 & 0.25 & 0.34 & 0.58 & -0.12 & 0.52 & 411 \\
\hline Knowledge & 0.39 & 0.43 & 0.15 & 0.12 & 0.69 & 0.83 & 581 \\
\hline Recognition & 0.39 & 0.37 & 0.17 & 0.13 & 0.66 & 0.77 & 598 \\
\hline Scale rel. (alpha) & 0.97 & 0.95 & 0.94 & 0.80 & 0.93 & & \\
\hline Eigenvalues & 19.49 & 2.79 & 1.84 & 1.20 & 1.02 & & \\
\hline$\%$ of variance & 24.74 & 17.11 & 15.73 & 9.28 & 6.31 & & \\
\hline Cumulative \% & 24.74 & 41.86 & 57.59 & 66.87 & 73.17 & & \\
\hline Kaiser-Meyer-Ol & kin Measure 0 & f Sampling & Adequacy: $\mathbf{0 .}$ & & Df: 630 & & \\
\hline Bartlett's Test of s & Sphericity/App & rox. Chi-Sc & uare: 10156 & & Sig.: $0.00 * * *$ & & \\
\hline
\end{tabular}

$* * *=$ significant at the $1 \%$ level. 


\section{TABLES AND FIGURES}

Table 1. Refined brand image model (based on factor analysis of the Persson model)

\begin{tabular}{lrcrl}
\hline \hline Factor name & $\begin{array}{l}\text { No. of } \\
\text { items }\end{array}$ & $\begin{array}{l}\text { Scale reliability } \\
\text { (alpha) }\end{array}$ & $\begin{array}{l}\text { \% of } \\
\text { variance }\end{array}$ & $\begin{array}{l}\text { Example of item (see all items in } \\
\text { appendix). }\end{array}$ \\
\hline Service relationship & 13 & 0.97 & 24.74 & "Flexible and adaptive" \\
Product solution & 9 & 0.95 & 17.11 & "Product quality" \\
Company reputation & 8 & 0.94 & 15.73 & $\begin{array}{l}\text { "A well-managed company" } \\
\text { "Buying or using products from this } \\
\text { company feels like belonging to a } \\
\text { community" } \\
\text { Brand community }\end{array}$ \\
Brand familiarity & 4 & 0.80 & 9.28 & $\begin{array}{l}\text { "I know what this company stands for } \\
\text { and has to offer" }\end{array}$ \\
\hline \hline
\end{tabular}

Table 2. Factor analysis of brand strength

\begin{tabular}{|c|c|c|c|c|}
\hline & \multicolumn{2}{|c|}{$\begin{array}{l}\text { Rotated component } \\
\text { matrix solutions }\end{array}$} & \multirow[b]{2}{*}{ Commu-nalities } & \multirow[b]{2}{*}{ Analysis N } \\
\hline & $\begin{array}{l}\text { Brand } \\
\text { loyalty }\end{array}$ & $\begin{array}{c}\text { Price } \\
\text { premium }\end{array}$ & & \\
\hline $\begin{array}{l}\text { Purchase intention } \\
\text { (short-term) }\end{array}$ & 0.90 & 0.05 & 0.81 & 380 \\
\hline $\begin{array}{l}\text { Purchase intention } \\
\text { (long-term) }\end{array}$ & 0.88 & 0.05 & 0.78 & 380 \\
\hline Recommendation & 0.87 & 0.08 & 0.77 & 380 \\
\hline Price premium 1 & -0.01 & 0.91 & 0.82 & 380 \\
\hline Price premium 2 & 0.08 & 0.90 & 0.83 & 380 \\
\hline Price sensitivity & 0.10 & 0.74 & 0.55 & 380 \\
\hline Scale rel. (alpha) & 0.88 & 0.82 & & \\
\hline Eigenvalues & 2.59 & 1.97 & & \\
\hline$\%$ of variance & 43.18 & 32.79 & & \\
\hline Cumulative \% & 43.18 & 45.97 & & \\
\hline \multicolumn{5}{|c|}{ Kaiser-Meyer-Olkin Measure of Sampling Adequacy: 0.70} \\
\hline \multicolumn{3}{|c|}{ Bartlett's Test of Sphericity/Approx. Chi-Square: } & \multicolumn{2}{|l|}{1047} \\
\hline \multicolumn{3}{|l|}{ Sig. } & \multicolumn{2}{|l|}{$0.000 * * *$} \\
\hline
\end{tabular}


Table 3. Regression analysis of the brand image-brand strength relationship

\begin{tabular}{|c|c|c|c|c|c|c|}
\hline \multirow[b]{4}{*}{ Brand image factor } & \multicolumn{6}{|c|}{ Dependent brand strength variables } \\
\hline & \multicolumn{3}{|c|}{ Brand loyalty } & \multicolumn{3}{|c|}{ Price premium } \\
\hline & \multicolumn{2}{|c|}{$\begin{array}{l}\text { Standardized } \\
\text { coefficients }\end{array}$} & $\begin{array}{l}\text { Collinearity } \\
\text { statistics }\end{array}$ & \multicolumn{2}{|c|}{$\begin{array}{l}\text { Standardized } \\
\text { coefficients }\end{array}$} & \multirow{2}{*}{$\begin{array}{r}\begin{array}{c}\text { Collinearity } \\
\text { statistics }\end{array} \\
\text { VIF }\end{array}$} \\
\hline & Beta & Sig. & VIF & Beta & Sig. & \\
\hline Company reputation & 0.43 & $0.000 * * *$ & 1.10 & -0.09 & n.s. & 1.05 \\
\hline Service relationship & 0.39 & $0.000 * * *$ & 1.05 & 0.05 & n.s. & 1.10 \\
\hline Product solution & 0.35 & $0.000 * * *$ & 1.06 & -0.01 & n.s. & 1.06 \\
\hline Brand community & 0.14 & $0.002 * * *$ & 1.01 & 0.44 & $0.000 * * *$ & 1.01 \\
\hline Brand familiarity & 0.14 & $0.003 * * *$ & 1.01 & -0.16 & $0.023 * *$ & 1.01 \\
\hline R2 adj. & \multicolumn{3}{|l|}{0.64} & \multicolumn{3}{|l|}{0.22} \\
\hline St. error of est. & \multicolumn{3}{|l|}{0.80} & \multicolumn{3}{|l|}{1.40} \\
\hline $\mathrm{F}$ & \multicolumn{3}{|l|}{63.21} & \multicolumn{3}{|l|}{10.86} \\
\hline Sig. F & \multicolumn{3}{|c|}{$0.000 * * *$} & \multicolumn{3}{|c|}{$0.000 * * *$} \\
\hline Df & \multicolumn{3}{|l|}{176} & \multicolumn{3}{|l|}{176} \\
\hline
\end{tabular}

$* *=$ significant at the $5 \%$ level. $* * *=$ significant at the $1 \%$ level.

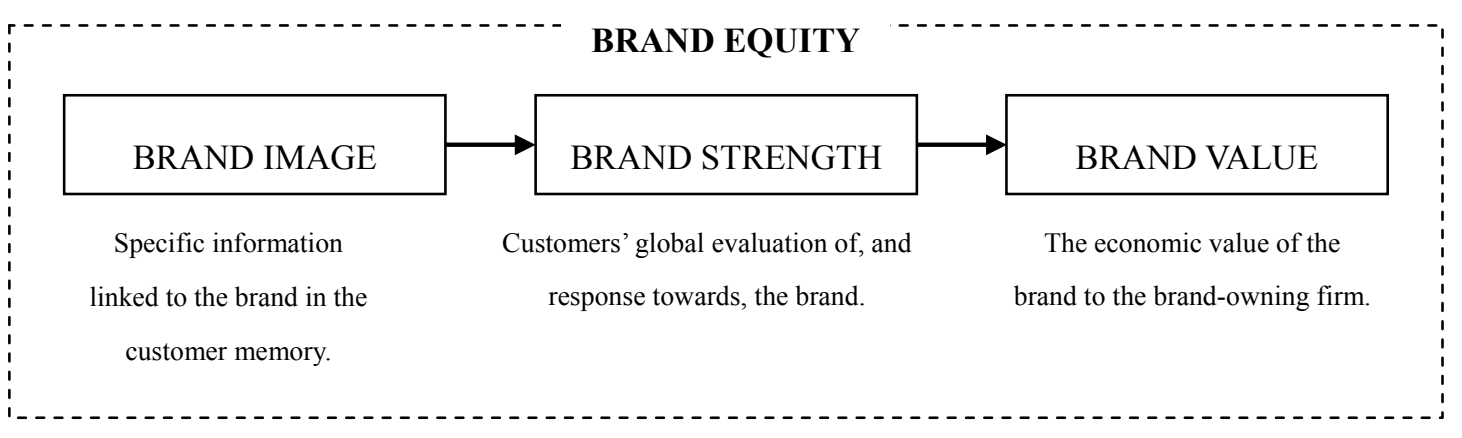

Figure 1 . The brand equity chain 


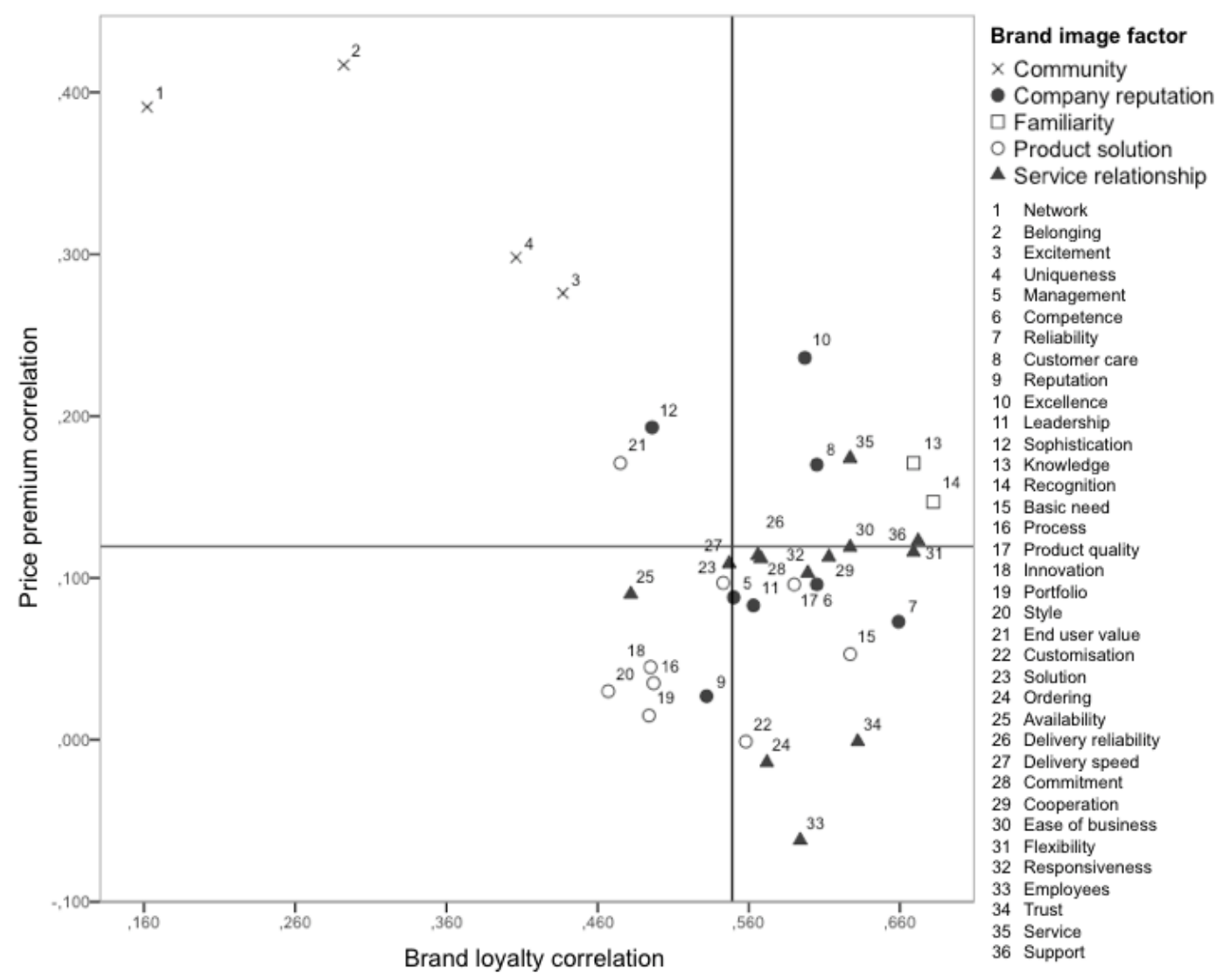

Figure 2. Correlation analysis on individual brand image item levels 